\title{
List of Illustrations
}

1. Moscow street, Gazetnyi pereulok, around the turn of the century. (V. A. Giliarovskii, Moskva i moskvichi, Moscow, 1968, following P. 416)

2. Religious ceremonies on the shop floor, such as this one at a metalworking plant in the Urals, were commonplace in factories throughout Russia at the beginning of the twentieth century. (Hoover Institution Archives, Foss Collection)

3. Patternmaking shop in a Petersburg shipbuilding plant, 1903. (K. A. Kuznetsov, L. Z. Livshits, and V. I. Pliasunov, Baltiiskii sudostroitel'nyi 1856-1917. Ocherk istorii Baltiiskogo sudostroitel'nogo zavoda imeni S. Ordzbomikidze, Leningrad, 1970, p. 174)

4. Corner of a room rented by a Petersburg metalworker and his family in the 1890s. (Ocherki istorii Leningrada, Moscow, 1957, III, p. 132)

5. Shell shop in St. Petersburg's giant Putilov plant in the early 1900s. (Istoriia rabochikh Leningrada, Leningrad, 1972, I, following page 480) 
6. Machine shop in a Petersburg shipbuilding plant around 1900. The shop mainly employed metalfitters. (Kuznetsov, Livshits, and Pliasunov, Baltiiski sudostroitel'nyi, p. 163)

7. Canteen in the early 1900 s where Petersburg workers took their meals. (Ocherki istorii Leningrada, III, p. 133)

8. Moscow's Prokhorovskaia Trekhgornaia textile mill in the early 1890s. (Materialy $k$ istorii Prokborovskoi trekhgornoi manufaktury, Moscow, 1913, p. 291)

9. Factory barracks at Moscow's Prokhorovskaia Trekhgornaia textile mill in the 1890s. (Istoriia Moskvy, Moscow, 1955, 5 , p. 63)

10. Women workers at a Moscow silk mill in the 1890s. (Kyril Fitzlyon and Tatiana Browning, Before the Revolution: A View of Russia Under the Last Tsar, London, 1977, p. 132; photo courtesy of Margot Tracey)

11. Spinning room in a textile mill with two child workers in the early 1900s. (Materialy $k$ istorii Prokborouskoi trekhgornoi manufaktury, p. 306)

12. Mandl' tailoring firm on Petersburg's Nevskii Prospect at the turn of the century. This branch of the Moscow-based Mandl' firm opened in 1886. (I. N. Bozherianov, Nevskii prospekt 1703-1903, St. Petersburg, 1902, p. xiii)

13. Tailors asleep on the workshop floor, 1890s. (Ocherki istorii Leningrada, Moscow, 1957, II, p. 209)

14. Male apprentices learning to sew and to iron in a Moscow tailoring shop. (L. Nikulin and G. Ryklin, eds., $V$ staroi Moskve. Kak khoziainichali kuptsy i fabrikanty, Moscow, 1939, following p. 208)

15. Apprentices and salesclerks in a Petersburg stationery store, 1900 (Bozherianov, Nevskii prospekt, p. iv)

16. Stores on Petersburg's fashionable Nevskii Prospect where many salesclerks found employment. (Bozherianov, Nevskii prospekt, Table XI) 
